\title{
The first external quality assurance laboratory proficiency assessment study of national antimicrobial resistance surveillance system in Turkey
}

\section{Tưrkiye'deki ulusal antimikrobiyal direnç sủrveyans sisteminin ilk diş kalite guivencesi laboratuvar yeterlilik değerlendirmesi}

\author{
Nilay ÇÖPLÜ1, Zeynep GÜLAY ${ }^{2}$, Fehminaz TEMEL ${ }^{3}$, Hüsniye ŞiMȘEK ${ }^{4}$, Neșe GÖL , \\ Dilber AKTAŞ ${ }^{3}$, Gülçin BAYRAMOĞLU ${ }^{5}$, Cüneyt ÖZAKIN ${ }^{6}$, Mete EYIGÖR ${ }^{7}$, \\ Duygu PERÇiNN ${ }^{8}$, Kezban GÜRDOĞAN ${ }^{4}$, Murad BAYRAM ${ }^{9}$
}

\section{ABSTRACT \\ Objective: National Antimicrobial Resistance} Surveillance System (NAMRSS) was established aiming to determine and track the percentage of antimicrobial resistance in Turkey, and in order to assure the reliability of the system, an external quality assurance laboratory proficiency assessment was performed in September 2011, for the first time.

Methods: Four bacterial strains were sent to 77 participating laboratories. The laboratories were asked to perform the bacterial identification and antimicrobial susceptibility tests (AST) according to standard operating procedures of NAMRSS and Clinical and Laboratory Standards Institute. The results were collected using a web-based questionnaire and the data were analysed using SPSS 15.00. Bacterial identification scoring was defined as ten points when genus and species were accurately defined, eight points when genus was accurate but species was wrong, and zero point when

\section{ÖZET}

Amaç: Ulusal Antimikrobiyal Direnç Sürveyans Sistemi (UAMDSS), Türkiye'de antimikrobiyal direnç yüzdelerini saptamak ve takip etmek amacıyla kurulmuștur. Sistemin güvenilirliğini sağlamak amacıyla Eylül 2011'de ilk kez dıș kalite güvence için laboratuvar yeterlilik değerlendirmesi gerçekleștirilmiștir.

Yöntem: Katılımcı 77 laboratuvarın her birine dörder bakteri suşu gönderilmiștir. Laboratuvarların UAMDSS standart uygulama prosedürleri ve Klinik Laboratuvar Enstitüsünün bakteri tanımlaması ve antibiyotik duyarılık testlerini (ADT) yapmaları istenmiștir. Sonuçlar, web-tabanlı bir anket ile toplanmıș ve veriler SPSS 15.00 ile analiz edilmiștir. Bakteriyel tanımlama skoru, cins ve tür düzeyinde doğru tanımlandığında on puan, cins doğru fakat tür hatalı olduğunda sekiz puan, yanlış tanımlandığında, rapor edilmediğinde ya da kontamine edildiğinde sıfır puan olarak tanımlanmıștır. ATD skorlaması her antibiyotik için doğru sonuç

${ }^{1}$ Kastamonu University, Kastamonu Medical School, Microbiology Department, Kastamonu

${ }^{2}$ Dokuz Eylül University, School of Medicine, Department of Microbiology, Izmir

${ }^{3}$ Public Health Agency of Turkey, Directorate of Early Warning and Response System and Field Epidemiology, Ankara

${ }^{4}$ Public Health Agency of Turkey, Directorate of Microbiology Reference Laboratories, Ankara

${ }^{5}$ Karadeniz Technical University, School of Medicine, Department of Microbiology, Trabzon

'Uludag University, School of Medicine, Department of Microbiology, Bursa

${ }^{7}$ Akdeniz University, School of Medicine, Department of Microbiology, Antalya

${ }^{8}$ Erciyes University, School of Medicine, Department of Microbiology, Kayseri

${ }^{9}$ Public Health Agency of Turkey, Directorate of Software, Ankara

DOI ID : 10.5505/TurkHijyen.2018.10437

Cöplü N, Gülay Z, Temel F, Șimșek H, Göl N, Aktaș D, Bayramoğlu G, Özakın C, Eyigör M, Perçin D, Gürdoğan K, Bayram M. The first external quality assurance laboratory proficiency assesment study of national antimicrobial resistance surveillance system in Turkey. Turk Hij Den Biyol Derg, 2018; 75(2): 117-126 
it was misdiagnosed or not reported or contaminated AST scoring included ten points per antibiotic when the result was correct. Two points were subtracted in case of a minor error (reported as susceptible or resistant when intermediate) and ten points in the case of a major or very major error (reported resistant when susceptable or as susceptible when resistant, respectively) during AST. The threshold value was determined as $70 \%$.

Results: From the system, 68 laboratories had sent data and analysed. For Klebsiella pneumoniae, Streptococcus pneumoniae, Enterococcus faecium and Pseudomonas aeruginosa the success percentage for the identification of were $92.6 \% ; 91.2 \% ; 89.7 \%$ and $98.5 \%$, respectively; and for AST the median/maximum score that could be achieved were 50/80; 28/50; $40 / 40$ and 60/60, respectively. When the success percentages were classified as $\leq 69.99 \% ; 70.00 \%-89.99 \%$ and $\geq 90.00 \%$, the distribution of the number of the laboratories were 10; 48; and 10 for the success percentage classes, respectively.

Conclusion: In this study, the system was considered reliable.

Key Words: quality control, drug resistance, microbial, surveillance, Turkey

\section{INTRODUCTION}

National Antimicrobial Resistance Surveillance System (NAMRSS) was established aiming to determine and track the percentage of antimicrobial resistance for the selected indicator bacteria and antimicrobials throughout the country in Turkey. For this purpose, a questionnaire was performed by participation of 322 laboratories from 12 regions determined by Turkey Nomenclature Units of Territorial for Statistics. Among them 77 laboratories were selected for the system which were university, training and research, and state hospitals, according to their score values and distribution equality over the country and institutions (1). The questionnaire included 90 queries which were focused on the capacity of culture performance including blood culture, and verdiğinde 10 puan olarak tanımlanmıștır. ADT sırasında minör hata olduğunda (orta duyarlı iken duyarlı ya da dirençli rapor edildiğinde) iki puan çıkarılmış, major ya da çok major hata (sırasıyla duyarlı iken dirençli ve dirençli iken duyarlı rapor edildiğinde) 10 puan çıkarılmıștır. Eșik değer, \%70 olarak belirlenmiștir.

Bulgular: Sistemden sonuç gönderen 68 laboratuvarın sonuçları analiz edilmiștir. Klebsiella pneumoniae, Streptococcus pneumoniae, Enterococcus faecium ve Pseudomonas aeruginosa için tanımlamada bașarı sırası ile \%92,6; \%91,2; \%89,7 ve \%98,5; ADT için ulașılabilen median/maksimum skorlar sirası ile 50/80; 28/50; $40 / 40$ ve $60 / 60$ olarak belirlenmiștir. Toplam bașarı yüzdeleri $\leq \% 69,99 ; \% 70,00-\% 89,99$ ve $\geq \% 90,00$ olarak sınıflandırıldığında, laboratuvarların bu sınıflara dağılımı sırası ile 10; 48 ve 10 șeklinde bulunmuștur.

Sonuç: Bu çalıșmada, sistemin güvenilir olduğunu düșündürmüștür.

Anahtar Kelimeler: kalite kontrol, ilaç direnci, mikrobiyal, sürveyans, Türkiye

AST which were based on World Health Organisation (WHO) documents (2). The staff of the laboratories had received a course about software WHONET and standard operating procedures (SOP's) which were in accordance with the international surveillance systems (3-6). After the course, they have been asked to study the antimicrobial susceptibility tests for indicator antimicrobials for E.coli, K. pneumoniae, P. aeruginosa, E. faecalis and E. faecium, S. aureus, S. pneumoniae isolated from blood or CSF, and send their results to Turkish Public Health Centre (TPHC) by using WHONET software $(3,4)$.

On the other hand, the isolates were not sent to the TPHC, so that there was still need to perform external quality assurance (EQA) studies in order to 
rely on the data of the system. Other international systems have performed EQA studies for the same purposes (5-7). For EQA, to collect and analyse the internal quality control (IQC) data, ii. observation on sight study, iii.retest a certain percentage of resistant strains and iv. laboratory proficiency assessment (LPA) were planned. Observation on sight study was done by visiting 25 of 77 laboratories in 2011 (8).

This LPA was another EQA study, which was performed in 2011, as the first quality study of NAMRSS together with observation on sight study, aiming to determine the accuracy of the reported results of the susceptibility test by individual laboratories and to estimate the overall comparability of the collected test results between laboratories across the country.

\section{MATERIAL and METHOD}

A main scopes: WHO document was used to plan EQA LPA $(9,10)$. This first LPA of the NAMRSS EQA was started by sending four bacteria strains to 77 participating laboratories on 20 September 2011 $(11,12)$. Five of these laboratories belong to the quality control (QC) subcommittee which had worked on the strains previously, and were included the study to address issues which might develop throughout the assessment. The laboratories were asked to perform the bacterial identification and antimicrobial susceptibility tests according to SOP of NAMRSS and CLSI $(3,4)$. The results of bacterial identification and antibiotic susceptibility tests were collected using a web-based questionnaire and the results were analysed using SPSS 15.00 .

Bacterial identification: It could be done by only automated systems or additional conventional tests, which depends on the laboratories choice. Bacterial identification scoring was defined as ten points when genus and species were accurately defined, eight points when genus was accurate but species was wrong, and zero point when it was misdiagnosed or not reported or contaminated. If only automated system had been used, scoring included ten points for identification according to the definition. In case the conventional tests were added, second ten points were included for identification tests. The bacteria those were sent to the laboratories, and if running, the conventional tests those were defined in the SOP (4) to be performed for identification were Klebsiella pneumoniae: colony morphology, microscopy, TSI, imvic, urea, motility, oxidase test; Streptococcus pneumoniae: microscopy, optochin resistance, bile solubility; Enterococcus faecium: catalase, growth at $6.5 \% \mathrm{NaCl}$ or PYR; Pseudomonas aeruginosa colony morphology, microscopy, TSI, oxidase test. For each bacterium, number of conventional tests were different, so that $10 / 7$ points for each test that had a correct result could be received when $K$. pneumoniae was studied, because there were seven tests to be performed for this bacterium. Likewise, the points those could be received for each test were 10/3, 10/2 and $10 / 4$ for $S$. pneumoniae, E. faecium and $P$. aeruginosa, respectively.

AST: The antibiotics those were expected to be studied for AST for the selected bacteria were as follows: amoxicillin or ampicillin, amikacin or gentamicin or tobramycin; levofloxacin or ofloxacin or ciprofloxacin, nalidixic acid, cefotaxime or ceftriaxone, ceftazidime, and ESBL presence for K. pneumonia; oxacillin, penicillin (MIC value), erythromycin, cefotaxime or ceftriaxone (MIC value), and norfloxacin for S. pneumonia; amoxicillin or ampicillin, gentamicin (120 $\mu \mathrm{g}$ disk), streptomycin (300 $\mu \mathrm{g}$ disk), and vancomycin (MIC value) for $E$. faecium; piperacillin or piperacillin/tazobactam, amikacin or gentamicin or tobramycin, ciprofloxacin or levofloxacin, ceftazidime, imipenem, and meropenem for $P$. aeruginosa, according to the SOP $(3,4)$. Scoring included ten points per antibiotic for AST. Two points were subtracted in case of a minor error (reported as susceptible or resistant when intermediate) and ten points in the case of a major or very major error (reported resistant when susceptable or as susceptible when resistant, respectively) during AST $(11,13)$. 
Evaluation criteria: The maximum score that could be achieved altogether by identification and antibiotic susceptibility testing were 80/90; $60 / 70$; $50 / 60$ and $70 / 80$ for automated methods/ conventional methods for $K$. pneumoniae, $S$. pneumoniae, $E$. faecium and $P$. aeruginosa, respectively. The assessment was based on success percentage so that the standardization could be achieved. The threshold value for the percentage of success was determined as $70 \%$, arbitrarily.

\section{RESULTS}

The laboratories involved: The results of the QC subcommittee laboratories as well as the other participating laboratories showed that no problem have developed during the process; therefore the results of the five each $\mathrm{QC}$ subcommittee laboratories were excluded from the assessment to prevent any potential influence on the analysis of the results. Besides, four laboratories did not send data, so that $94.8 \%$ of the laboratories had participated in the study. As a result, data of 68 laboratories were analysed for EQA LPA in total. The number of the laboratories participated were: seven each from Ankara; five each from Istanbul; three each from Adana, Antalya and Erzurum; two each from Izmir, Diyarbakir, Eskisehir, Gaziantep, Konya, Samsun, Tekirdağ, Tokat; and one from each of the other 31 province.

Bacterial identification: 23 of the laboratories used only automated system for identification of the bacteria and others used conventional methods in addition (Table 1). The distributions of laboratories where only automated system have been used for identification were 52.9\%, 50.0\%, 48.5\%, and 33.8\%; for E.faecium, P.aeruginosa, K.pneumoniae, and S.pneumoniae, respectively.

The conventional tests were used by 45 laboratories. The distribution of laboratories using conventional methods for S.pneumoniae, K.pneumoniae, P.aeruginosa, and E.faecium were: 45, 35, 34 and 32, respectively.

The distribution of the bacterial success of identification (ten score points) of the participating laboratories for K. pneumoniae, S. pneumoniae, E.faecium and P.aeruginosa were 92.6\%; 91.2\%; $89.7 \%$ and $98.5 \%$, respectively (Table 2 ). When misidentification reasons have been analyzed, it was observed that for K.pneumoniae five laboratories couldn't perform identification even genus level and identified as E.coli (three laboratories), Pseudomonas aeruginosa (one laboratory) and one laboratory declared that wrong strain has been sent, so that they received zero score point.

Table 1. Distribution of laboratories involved in NAMRSS EQA LPA by number of strains analysed using conventional methods

\begin{tabular}{|c|c|c|}
\hline Number of strains analyzed using conventional methods & Number of laboratories & \% \\
\hline $0^{*}$ & 23 & 33.8 \\
1 & 9 & 3.2 \\
2 & 2 & 5.9 \\
3 & 4 & 44.1 \\
\hline 4 & 68 & 100.0 \\
\hline
\end{tabular}

* 23 laboratories used only automated system for identification. 
Table 2. Success of identification of the four strains of the participating laboratories (max. score:ten for each bacterial).

\begin{tabular}{|c|c|c|}
\hline Score & Number of laboratories & $\%$ \\
\hline \multicolumn{3}{|c|}{ K.pneumoniae* } \\
\hline 10 & 63 & 92.6 \\
\hline 0 & 5 & 7.4 \\
\hline \multicolumn{3}{|c|}{ S. pneumonia ${ }^{* *}$} \\
\hline 10 & 62 & 91.2 \\
\hline 8 & 1 & 1.5 \\
\hline 0 & 5 & 7.3 \\
\hline \multicolumn{3}{|c|}{ E. faecium } \\
\hline 10 & 61 & 89.7 \\
\hline 8 & 5 & 7.4 \\
\hline 0 & 2 & 2.9 \\
\hline \multicolumn{3}{|c|}{ P. aeruginosa } \\
\hline 10 & 67 & 98.5 \\
\hline 8 & 1 & 1.5 \\
\hline Total & 68 & 100.0 \\
\hline \multicolumn{3}{|c|}{$\begin{array}{l}\text { ** Two laboratories did not work on this strain due to defects in the sample shipping. This } \\
\text { strain was excluded when success rate was calculated for these two laboratories. } \\
0: \text { Not reported or misdiagnosis or contamination } \\
\text { 8: Error at species level }\end{array}$} \\
\hline
\end{tabular}

For S.pneumoniae, one laboratory identified as Streptococcus mitis and received eight score point; two laboratories identified as K.pneumoniae, and each of other three laboratories identified as Aspergillus spp. unknown, and no growth.

For E.faecium, five laboratories received eight score points because they couldn't identify to species level (one of them identified as E.faecalis). Two of the laboratories identified as S.aureus and received zero score point.

For P.aeruginosa, only one laboratory missed identification to species level and received eight score points.

AST: Scores of the laboratories showed that there was no laboratory which could get maximum score for K.pneumoniae that was 80 score points, and the median was 50. For S.pneumoniae, $7.3 \%$ laboratories could get maximum score point which was 50 and the median was 28. Contrarily, maximum score could be achieved by $61.8 \%$ and $63.2 \%$ for $E$. faecium and $P$. aeruginosa, respectively, and the median scores were the same as the maximum scores for both bacteria (Table 3).

When error levels were analysed, it was found that for K.pneumoniae: for amikacin there were 1/62 major, 18/62 minor error; for ofloxacin and levofloxacin $1 / 9$ and $1 / 49$ very major error, respectively. There was no error for E.faecium. The error levels for $P$. aeruginosa and $S$. pneumoniae were presented in Table 4 . The most common errors were oxacillin, penicillin and norfloxacin for S.pneumoniae. On the other hand, the error were below $10 \%$ for the other antimicrobials for S.pneumoniae and all of the antimicrobials for P.aeruginosa. 
Table 3. Antimicrobial susceptibility test scores of the laboratories for four strains

\begin{tabular}{|c|c|c|}
\hline Score & Number of laboratories & $\%$ \\
\hline \multicolumn{3}{|l|}{ K. pneumoniae (Max: 80) } \\
\hline 0 & 1 & 1.5 \\
\hline 30 & 2 & 2.9 \\
\hline 40 & 16 & 23.5 \\
\hline 50 & 42 & 61.8 \\
\hline 60 & 7 & 10.3 \\
\hline \multicolumn{3}{|l|}{ ESBL } \\
\hline 0 & 11 & 16.2 \\
\hline 10 & 57 & 83.8 \\
\hline Mean \pm sd; Median (Min-Max) & \multicolumn{2}{|c|}{$47.4 \pm 8.7 ; 50(0-60)$} \\
\hline \multicolumn{3}{|l|}{ S. pneumoniae (Max: 50) } \\
\hline 0 & 7 & 10.3 \\
\hline 10 & 9 & 13.2 \\
\hline 15 & 1 & 1.5 \\
\hline 20 & 14 & 20.6 \\
\hline 25 & 2 & 2.9 \\
\hline 28 & 4 & 5.9 \\
\hline 30 & 17 & 25.0 \\
\hline 35 & 1 & 1.5 \\
\hline 38 & 1 & 1.5 \\
\hline 40 & 4 & 5.9 \\
\hline 45 & 1 & 1.5 \\
\hline 48 & 2 & 2.9 \\
\hline 50 & 5 & 7.3 \\
\hline Mean \pm sd; Median (Min-Max) & \multicolumn{2}{|c|}{$24.7 \pm 14.0 ; 28(0-50)$} \\
\hline \multicolumn{3}{|l|}{ E. faecium (Max: 40) } \\
\hline 10 & 3 & 4.4 \\
\hline 20 & 3 & 4.4 \\
\hline 30 & 20 & 29.4 \\
\hline 40 & 42 & 61.8 \\
\hline Mean \pm sd; Median (Min-Max) & \multicolumn{2}{|c|}{$34.9 \pm 7.8 ; 40(10-40)$} \\
\hline
\end{tabular}

P. aeruginosa (Max: 60)

20

40

45

50

55

58

60

Mean \pm sd; Median (Min-Max)

Total

ESBL: Extanded Spectrum Beta Lactamases
1.5

2.9

2,9

26.5

1.5

1.5

63.2

$55.6 \pm 7.1 ; 60$ (20-60) 
Table 4. Error levels of antimicrobial susceptibility tests for $P$. aeruginosa and S. pneumoniae

\begin{tabular}{|c|c|c|c|c|c|c|c|c|}
\hline 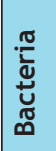 & Antimicrobials & $\mathrm{n}^{*}$ & $\mathrm{R} / \mathrm{S} / \mathrm{I}$ & $\begin{array}{l}\text { Very major } \\
\text { error }\end{array}$ & $\begin{array}{l}\text { Major } \\
\text { error }\end{array}$ & $\begin{array}{l}\text { Minor } \\
\text { error }\end{array}$ & $\begin{array}{c}\mathrm{n} \text { of labs. } \\
\text { engaged in } \\
\text { error }\end{array}$ & $\begin{array}{c}\text { Error level } \\
\%^{* *}\end{array}$ \\
\hline \multirow{10}{*}{ 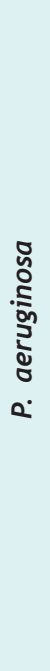 } & Piperacillin & 36 & $S$ & - & - & - & - & - \\
\hline & Piperacillin/Tazobactam & 58 & $S$ & - & 4 & - & 4 & 6.9 \\
\hline & Amikacin & 63 & $S$ & - & - & - & - & - \\
\hline & Gentamicin & 63 & $S$ & - & - & - & - & - \\
\hline & Tobramycin & 17 & $S$ & - & - & - & - & - \\
\hline & Ciprofloxasin & 59 & $S$ & - & 1 & - & 1 & 1.7 \\
\hline & Levofloxacin & 49 & $S$ & - & 2 & - & 2 & 4.1 \\
\hline & Ceftazidime & 62 & $S$ & - & 3 & 1 & 4 & 6.5 \\
\hline & Imipenem & 65 & $S$ & - & 2 & - & 2 & 3.1 \\
\hline & Meropenem & 60 & $S$ & - & 1 & - & 1 & 1.7 \\
\hline \multirow{6}{*}{ 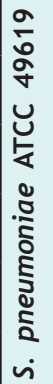 } & Oxacillin & 34 & $\mathrm{R}$ & 11 & - & - & 11 & 32.4 \\
\hline & Penicillin MIC & 39 & $S$ & - & 4 & 7 & 11 & 28.2 \\
\hline & Erytromycin & 56 & $S$ & - & 1 & - & 1 & 1.8 \\
\hline & Cefotaxim & 29 & $\mathrm{~S}$ & - & - & - & - & - \\
\hline & Ceftriaxone MIC & 22 & $S$ & - & 1 & - & 1 & 4.6 \\
\hline & Norfloxacin & 18 & $S$ & - & 2 & - & 2 & 11.1 \\
\hline
\end{tabular}

*Number of laboratories which sent results for the mentioned antimicrobial.

${ }^{* *}$ Error level= Number of laboratory engaged in error/number of laboratories which sent results for the mentioned antimicrobial.

Overall evaluation: The success percentages were classified as $\leq 49.99 \%$; $50.00-69.99 \%$; 70.00 $89.99 \%$ and $\geq 90.00 \%$, and the distribution of the number of the laboratories were 1; 9; 48 and 10 for the success percentage classes, respectively (Figure 1). Twenty laboratories success rate were in 85.00 89.99\% class for, which was the biggest group. There were ten laboratories which have performed below the threshold success percentage $70 \%$.

\section{DISCUSSION}

Assessment is a critical issue for laboratory quality management. One of the most common assessment methods is that of external quality assessment. EQA is a method that allows for comparison of a laboratory's testing to a source outside the laboratory which can be made to the performance of a peer group of laboratories or to the performance of a reference 


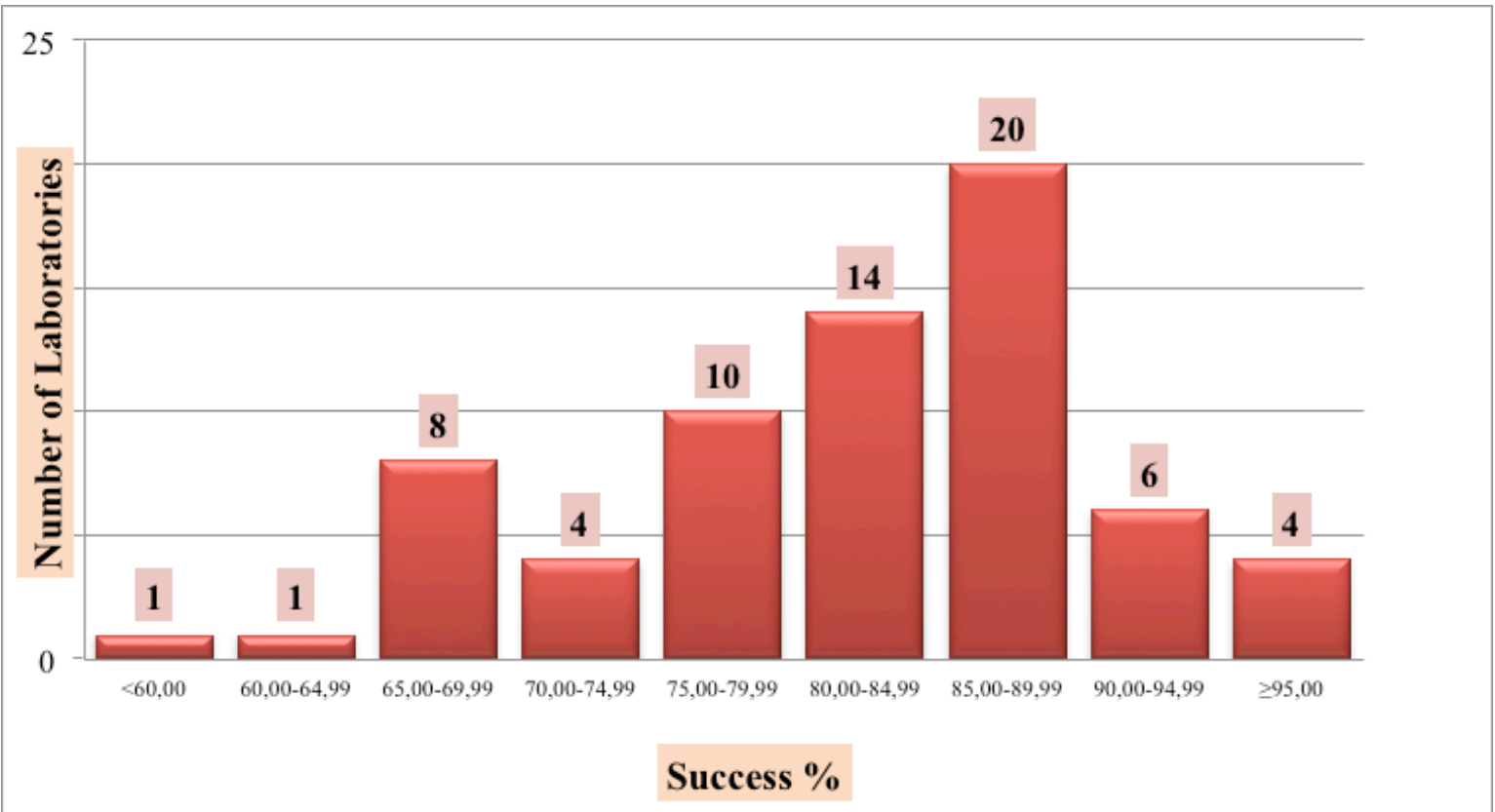

Figure 1. The distribution of the number of laboratories according to the success percentages for bacterial identification and antimicrobial susceptibility testing for four strains

laboratory (9). In this assessment, we compared performance of 68 laboratories to the performance of the QC subcommittee laboratories.

It is obvious that the quality of the surveillance system is directly influenced by the performance of the laboratories involved in NAMRSS. Although the selection of the laboratories was done through a questionnaire study (1), it was essential to do both IQC studies as well as EQA tests, and LPA was one of these studies. Only four of the laboratories didn't sent results and participation was high (94.8\%) (Figure 1). Participation in the EQA studies in Europe Annual report of the European Antimicrobial Resistance Surveillance Network (EARS-Net) 2010 (5), EARS-Net 2014 (14), and Central Asian and Eastern European Surveillance of Antimicrobial Resistance (CAESAR) Annual Report 2014 (6) were 88\%, 92\%, and 92\% respectively, and our participation percentage was similar to these reports.

The laboratories where conventional tests were done, it was preferred to do this for at least some simple tests like microscopy, catalase, oxidase before working with automated system. For S. pneumoniae, microscopy has a distinctive feature which may be the reason for all the laboratories those prefer to perform conventional tests. According to the surveillance report of the EARS-Net in 2010 (5), laboratories used automated (52\%) or conventional methods (46\%) for identification of the bacteria, and automated systems (42\%), disc diffusion tests (34\%) or combined methods (14\%) for AST. Increased use of conventional methods was associated with identification of the $S$. pneumoniae and E. faecium. Surveillance report of the EARS-Net in 2014, for species identification and AST, $56 \%$ of the participating laboratories used an automated and $44 \%$ used conventional methods. Increased use of conventional methods was associated with identification of the $S$. pneumoniae, which was similar to our study (14). Likewise, in CAESAR annual report (6) $49 \%$ of the laboratories used automated instrument, $47 \%$ used disc diffusion method, and $4 \%$ other methods in the LPA study. 
Besides, the identification of S.pneumoniae was correct in the results of $91.2 \%$ of the laboratories in our study. According to an ECDC external quality assurance study, 17 (89\%) laboratories have correctly identified S. pneumoniae (15). In our study, it was observed that maximum success was achieved for $P$. aeruginosa and the minimum was for E.faecium, but the scores were close to each other (Table 2).

When antimicrobial susceptibility test scores were analysed, it was observed that for $P$. aeruginosa and $E$. faecium, the results were satisfactory: for $E$. faecium there was no error, for $P$. aeruginosa there was no very major error. On the other hand, for $K$. pneumoniae the laboratories failed to receive maximum score, there were very major errors as well as major and minor errors. Error levels were similar for S. pneumoniae. NAMRSS is a member of CAESAR, and in annual report 2014, and the results of Turkey were defined as "level a data". In the report, the results of EQA study was included as well (6). From Turkey 72 of 78 laboratories had participated the EQA study where there were three strains in common with this study. When comparing the results, it was observed that success has been improved according to CAESAR report: for $K$. pneumoniae both aminoglycosides and fluoroquinolones were $100 \%$; for S. pneumoniae oxacillin (98\%), penicillin $(56 \%$ for meningitis, $92 \%$ for other than meningitis), eritromycin (100\%), ceftriaxone ( $97 \%$ for meningitis, $82 \%$ for other than meningitis) and norfloxacin (92\%) showed better results (6). For $P$. aeruginosa, it was observed that piperacillin/tazobactam error level has been increased from $6.9 \%$ (NAMRSS) to $43 \%$ (CAESAR), but for the other antimicrobials the results were similar, success percentages changed in between $96-100 \%$. Piperacillin/ tazobactam success level was 57\% for P.aeruginosa in EARS-Net 2010 (5), which was close to the results in CAESAR from Turkey (6). The results of CAESAR showed that NAMRSS success has been remained similar or have been improved in most instances.

SOP'S of NAMRSS is similar to EARS-Net, so the findings of our study were compared to the surveillance report of EARS-NET 2014 report. For AST, the correct results for $K$. pneumoniae were as: ESBL $67.2 \%$; amikacin $73.5 \%$, and the other antimicrobials 97.0$100.0 \%$. In our study, the error source was amikasin with one major 18 minor error, like EARS-Net (14). Likewise, the results for $\mathrm{S}$. pneumoniae for oxacillin there were $86.9 \%$ success, where for penicilin, depending the site of infection the success was changing in between 51.4 $94.1 \%$. For the other antimicrobials, the success was $88.2 \%$ for norfloxacin, but higher than $96.1 \%$ for the others (14). In our study, the most error source were oxacillin, penicillin and norfloxacin (Table 4) which was similar to EARS-Net. For $E$. faecium except for the high level gentamicin resistance with $90.9 \%$, the other antimicrobials had high concordance with the report (14).

Our results showed comparable results for the EQA studies of the other two surveillance systems. These systems had similar SOP's and were in close geographical region, so that the results of this EQA study is thought to be reliable.

The information received by LPA participation should be directed to improvement in the laboratory (9). The results of this assessment were used to give feedback to the laboratories to improve themselves, and the results of CAESAR 2014 report shows that laboratories had improved their tests. Besides, the LPA should not be used for any purpose other than internal quality improvement, so the provider or central organization generally prohibits the discussion of results with other laboratories (6). In this study, we also did not share our results with other laboratories but we have sent the result to each laboratory of concern.

It is important to remember that LPA does have some limitations and it is not appropriate to use only LPA for evaluating the quality of a laboratory $(6,9)$. For the laboratories involved in NAMRSS, observation on sight study was done in the same period and even though there were issues those need to be improved, the AST results seem to be reliable by this study $(2,8)$. Besides other EQA studies were planned to be done for the NAMRSS laboratories.

When looking at the overall success, very few laboratories were below the threshold and most of the laboratories were found to be successful so that the data of the system can be considered reliable. 


\section{ACKNOWLEDGMENTS}

We extend our thanks to Professor Dr. Mustafa Ertek, and Associate Professor Dr.Berrin Esen for their managerial and scientific guidance. Our thanks also go to WHO consultant Dr.Ray Sanders for scientific advice, and resident students and Biologist Demet Furkan Sevindi, Dr.Emek Türkekul Șen, Dr.Kenan Murat and Dr.Semra Kavas for their contribution in the laboratory work as well as the specialists of participating laboratories for their cooperation.

\section{REFERENCES}

1. Gözalan A, Çöplü $N$, Aktaș $D$, Şimșek H, Erdem GB, Mumcuoğlu I. Performance evaluation of the microbiology laboratories in Turkey for culture and antibiotic susceptibility tests and the selection of laboratories to provide data for national antimicrobial resistance surveillance system: questionnary application. Turk Hij Den Biyol Derg, 2015; 72(3): 175 - 82.

2. Anonmyous. Antimicrobial Resistance Surveillance Questionnaire for Assessment of National Networks WHO/CDS/ CSR/RMD/2003.1. World Health Organization. ht t p : / / w w w. who.int / d ru g r e s i s t a n c e / whocdscsrrmd20031.pdf?ua=1, (Accessed: December 12, 2015).

3. Anonmyous. M100S21 Performance Standards for Antimicrobial Susceptibility Testing. Vol. 31. No 1. USA: Clinical and Laboratory Standards Institute. 2011.

4. Anonmyous. National Antimicrobial Resistance Surveillance System Laboratory Tests, Quality Control and Quality Assurance Standard Opreating Procedure and WHONET Software Programme. 2011.

5. Anonmyous. Antimicrobial resistance surveillance in Europe Annual report of the European Antimicrobial Resistance Surveillance Network (EARS-Net) 2010. www.ecdc.europa.eu, (Accessed: December 12, 2015).

6. Anonmyous. Central Asian and Eastern European Surveillance of Antimicrobial Resistance, Annual Report 2014. World Health Organization. http://www.euro.who.int/_data/ assets/ pdf_file/0006/285405/CEASER-SurveillanceAntimicrobial-Resistance2014.pdf?ua=1, (Accessed: December 12, 2015).

7. Anonmyous. EU Laboratory Capability Monitoring System (EULabCap) Report on 2013 Survey of EU/ EEA Country Capabilities and Capacities. Swedish: Stockholm, 2016. doi 10.2900/63194.
8. Akbas E, Cöplü N, Simsek H, Esen B, Sezgin B. Laboratory Evaluation of susceptibility tests for national antimicrobial resistance surveillance system (NAMRSS) in Turkey. Turk Hij Den Biyol Derg, 2018; 75(1): 1-12.

9. Anonmyous. External Quality Assessment _ Module 10 _ Content Sheet. World Health Organization. http://www. who.int/ihr/training/laboratory_ quality/10 b eqa contents.pdf, (Accessed: December 12, 2015).

10. Anonmyous. Laboratory Quality Management System: Handbook. World Health Organization. http://whqlibdoc.who. int/ publications/2011/9789241548274_eng.pdf, (Accessed: December 12, 2015).

11. Anonmyous. http:// uamdss.thsk.gov.tr/images/ UAMDSS_report_English_9\%20april.pdf, (Accessed: December 12, 2015).

12. Anonmyous. National Antimicrobial Resistance Surveillance System, NAMRSS, Annual Report 2011. http:// uamdss.thsk.gov.tr/index. php?option=com_phocadownload\&view=categor y\&id=6:raporlar\&ltem id=13 Turkish, (Accessed: December 12, 2015).

13. Anonmyous. Cumitech 31A, Verification and Validation of Procedures In The Clinical Microbiology Laboratories. Washington: ASM Press, 2009.

14. Anonmyous. Antimicrobial Resistance Surveillance In Europe Annual Report of The European Antimicrobial Resistance Surveillance Network (EARS-Net) 2014. http://ecdc.europa. eu/ en/publications/Publications/antimicrobialresistance-europe-2014.pdf, (Accessed: December 12, 2015)

15. Anonmyous. European Centre For Disease Prevention And Control. External Quality Assurance Scheme For Streptococcus pneumoniae - 2012. Stockholm: ECDC, 2013. 